\title{
Permanent Sovereignty over Natural Resources
}

\author{
Yogesh Tyagi*
}

\begin{abstract}
Emerging from the North-South struggle of the 1960s and 1970s, the principle of permanent sovereignty over natural resources is a fundamental right of states, as well as of peoples. Both the principle and the right represent the resolve of developing countries to attain economic independence and to assert the authority of domestic law, albeit with a conflict of perceptions about the role of international law in this scheme. The principle is widely accepted, whereas the right is frequently contested. In the field of international human rights law, the peoples-oriented character of the right has shown its potential to outshine its state-centric nature. In the twentyfirst century, the debate over the permanent sovereignty over natural resources has resurfaced especially as a reaction to the litigious record of international investment law. As a result, the principle of permanent sovereignty over natural resources has once again become the rallying point for introducing reform in international investment law. The process of reform is taking different forms, such as states changing their model bilateral investment treaties (unilateralism) or renegotiating their existing bilateral investment treaties (bilateralism), although multilateralism continues to be neglected. This process needs to accompany a new kind of North-South dialogue to secure its wider acceptance in order to ensure a healthy development of the principle/right of permanent sovereignty over natural resources.
\end{abstract}

\section{Keywords}

Sovereignty, Resources, Self-determination, Economic Independence, International Investment

\section{Introduction}

According to the 1933 Montevideo Convention on the Rights and Duties of States, ${ }^{1}$ as adapted by the Badinter Arbitration Committee in $1991,{ }^{2}$ sovereignty is one of the

* Dean and Professor of Law, Faculty of Legal Studies, South Asian University (India); Member of the Law Commission of India. The author is thankful to Daniel H Joyner for his encouragement and support. The author gratefully acknowledges the help of Prabhash Ranjan regarding the section on international investment law. Thanks are due to Anne Burnett and Annie Paprocki for providing useful information and material.

1 Convention on Rights and Duties of States (adopted 26 December 1933, entered into force 26 December 1934) 165 LNTS 19 (Montevideo Convention).

2 Alain Pellet, 'The Opinions of the Badinter Arbitration Committee: A Second Breath for the SelfDetermination of Peoples' (1992) 3 EJIL 178, 182. 
essential attributes of statehood, and territory is another. ${ }^{3}$ Following the Montevideocum-Badinter definition of 'state', the concept of permanent sovereignty over natural resources (PSNR) seems to combine these two attributes of statehood. However, the combination of 'the sovereignty of States and the self-determination of peoples' has instead been given credit for the germination of the concept of PSNR. ${ }^{4}$ Although a wide range of rights relate to PSNR, the sovereign right of the state to possess, use, dispose, regulate and nationalise or expropriate natural resources in view of its national policies is the most important one. ${ }^{5}$ Likewise, a number of correlative duties exist, ${ }^{6}$ but the most important one is that the right to PSNR must be exercised in the interest of the national development and well-being of the people of the state concerned. ${ }^{7}$

The catalogue of rights, and that of duties, relating to the principle of PSNR remain uncertain, although the core rights and duties have more or less been identified. Besides other variables, changing national development policies and progressive development of international law would not easily allow for a final listing of the rights and duties. Furthermore, all the rights and duties flowing from PSNR are not equally recognised in international law. Certainly, not all rights and duties have clear content or precise meaning, or are of a uniform national priority. Moreover, the balance between the rights and the correlative duties is not accepted by all. ${ }^{8}$ Following the changing balance of economic power in the world, which is likely to witness the emergence of new haves and have-nots, a renewed interest in the concept of PSNR is inevitable. In spite of its considerable influence on international political economy, however, the concept has not attracted the attention of many international relations scholars.

The present study provides an overview of the legal status of PSNR and its state practice in two fields: international human rights law and international investment law. It enquires into the journey of the concept of PSNR to its recognition first as a principle, and then as a right. It attempts to identify various challenges in balancing the rights and duties of states, peoples and individuals in the given fields of study. And it will consider how the concept/principle/right of PSNR keeps the interests of the sovereign state at its core, yet remains sensitive to the interests of others. The paper will begin with a general review of the history of PSNR in international law. The second section

3 While 'sovereignty' is implicitly expressed in terms of 'government' with 'capacity to enter into relations with the other states', 'territory' is qualified as 'a defined territory', implying some degree of certainty and permanence. See Montevideo Convention, art 1.

4 See, among others, Nico Schrijver, Sovereignty over Natural Resources: Balancing Rights and Duties (CUP 1997) 368.

5 While in 1997 Schrijver identified five 'widely acknowledged' rights and five 'controversial' claims to rights (ibid 391), in 2009 Hofbauer listed only three: see Jane Hofbauer, 'The Principle of Permanent Sovereignty over Natural Resources and its Modern Implications' (LLM thesis, University of Iceland 2009) 13-29.

6 In 1997, Schrijver identified four duties: see Schrijver, Sovereignty over Natural Resources (n 4) 391-92.

7 Permanent Sovereignty over Natural Resources, UNGA Res 1803 (XVII) (14 December 1962) UN Doc A/RES/1803(XVII) (1962 Resolution) para 1.

8 For instance, unlike Schrijver, Sovereignty Over Natural Resources (n 4), Chimni is not satisfied with the balance between rights and duties. See Bhupinder S Chimni, 'The Principle of Permanent Sovereignty over Natural Resources: Toward a Radical Interpretation’ (1998) 38 IJIL 208, 213-14. 
will then focus on PSNR and its development in the specific context of international human rights law. The third section will chart the development and status of PSNR in the context of international investment law, where it has arguably received the highest level of attention. Finally, we will ask whether PSNR can be accurately characterised as a fundamental right of states in international law.

\section{Legal development and status of PSNR}

While the concept of sovereignty has existed for centuries, PSNR as a legal concept has relatively recent origins in international law. Initially appearing as a recommendation for 'concerted action for economic development of economically less developed countries,' PSNR found its first concrete expression in 1962 when the United Nations (UN) General Assembly almost unanimously adopted its resolution on Permanent Sovereignty over Natural Resources (1962 Resolution). Since then, a number of developments in various fora have contributed to the growth of PSNR as a legal concept. While a few advocates of PSNR want it to acquire the highest legal status, some of its detractors consider it no more than a political manifesto. ${ }^{10}$

Besides its different legal connotations, PSNR has been a dynamic concept to help assert state authority in time of legal uncertainty. PSNR has sought to achieve in the economic field what the right to self-determination has considerably accomplished in the political field: national independence. It provides a principled support to economic nationalism. PSNR finds its place in both international law and domestic law, although its international law dimensions generally dominate the discourse on the subject.

Being the first concrete expression of the principle of PSNR, the 1962 Resolution recognises the right of peoples and nations to permanent sovereignty over their natural wealth and resources, and the entitlement to exercise it in the interest of their national development and of the well-being of the people of the State concerned.'11 It further recognises the right of the host state to nationalise or expropriate the property of the foreign investor, provided that 'appropriate compensation' is paid in accordance with the applicable rules of domestic law and international law. ${ }^{12}$ It seeks to balance the rights of the host state with its duties. It contains provisions to protect the rights of the foreign investor, but it hardly has any space for listing the duties of the investor. Thus, the 1962 Resolution is not a radical departure from traditional international law. ${ }^{13}$

9 See Concerted Action for Economic Development of Economically Less Developed States, UNGA Res 1515 (XV) (15 December 1960) UN Doc A/RES/1515(XV) para 5.

10 See, eg, as advocate, Chimni (n 8); as detractor, Schrijver, Sovereignty over Natural Resources (n 4).

111962 Resolution, para 1.

12 ibid para 4.

13 Chimni (n 8) 208. 
The 1974 UN General Assembly Declaration on the Establishment of a New International Economic Order (NIEO Declaration) ${ }^{14}$ reaffirmed the principle of PSNR without mentioning the 1962 Resolution as such. ${ }^{15}$ In the NIEO Declaration, the principle of PSNR stands along with the principle of sovereign equality of states, ${ }^{16}$ which is one of the principles of the UN Charter. ${ }^{17}$ However, this normative affinity is rather misleading; a principle enshrined in the UN Charter cannot be equated with a principle merely recognised by a resolution of a political organ of the UN.

Interestingly, although the NIEO Declaration aimed at establishing a new world order, developed countries did not consider it a radical statement in international law. As part of their diplomacy, these countries did not have much difficulty in sympathising with the legitimate aspirations of developing countries without recognising them as legal rights. That is why developed countries did not vote against the adoption of the NIEO Declaration. Contrary to the lip service of most of the developed countries to the cause of economic justice, however, developing countries wanted to transform their legitimate aspirations into realities by evolving new standards of international law. Armed with their voting power in the UN General Assembly, these countries believed in the legitimacy of their cause.

Also adopted by the UN General Assembly following the 1972 initiative of the President of Mexico at the UN Conference on Trade and Development (UNCTAD), ${ }^{18}$ the 1974 Charter of Economic Rights and Duties of States (CERDS) ${ }^{19}$ sought to supplement the 1962 Resolution by presenting the principle of PSNR in the language of rights and duties. It recognised the rights of states, especially when a foreign investor is involved. It emphasised the primacy of domestic law in regulating foreign investment without rejecting the relevance of international law in this regard, although developed countries have read it differently. ${ }^{20}$ Since its balance of the rights and duties of states neither reinforces the status quo nor refers to international law, the CERDS appears to

14 Declaration on the Establishment of a New Economic Order, UNGA Res 3201 (S-VI) (1 May 1974) UN Doc A/RES/S-6/3201.

15 ibid para $4(\mathrm{e})$.

16 ibid para 4(a), 4(e).

17 Charter of the United Nations (adopted 26 June 1945, entered into force 24 October 1945) 892 UNTS 119 (UN Charter) art 2(1).

18 At the third session of UN Conference on Trade and Development (UNCTAD), held in Santiago, Chile, from 13 April to 21 May 1972, President Luis Echeverría of Mexico proposed the adoption of a Charter of Economic Rights and Duties of States, and UNCTAD decided to establish the Working Group on the Charter of the Economic Rights and Duties of States. Once the Working Group finalised the draft Charter, the Trade and Development Board of UNCTAD transmitted the draft to the UN General Assembly in September 1974.

19 Charter of Economic Rights and Duties of States, UNGA Res 3281 (XXIX) (12 December 1974) UN Doc A/RES/29/3281.

20 However, the Reporters of the US Restatement of the Foreign Relations Law note that in case of expropriation of property of a foreign national, the CERDS requires payment of 'appropriate compensation' in accordance with 'the law of the expropriating state, rejecting by implication any obligation of compensation under international law'. See Restatement (Third) of the Foreign Relations Law of the United States, vol 2 (American Law Institute 1987) 206. 
be a radical statement, and the international law orthodoxy did not like it. ${ }^{21}$ That is the reason for the Western chorus that the CERDS has no legal value. In the same vein, the Sole Arbitrator in the Texaco Arbitration observed that the CERDS 'must be analysed as a political rather than as a legal declaration. ${ }^{22}$ However, if a unilateral declaration may have legal effects in international law, ${ }^{23}$ it must be wondered why an international instrument adopted by the preponderant majority of the UN General Assembly has no legal value.

The use of the term 'Charter' in the CERDS is a misnomer-it indicates the ambitions of the drafters of the Charter, not its legal character. Like the 1962 Resolution, the CERDS is a resolution of the UN General Assembly. Unlike the former, however, the latter has been keenly contested on account of its textual radicalism, legal significance and political legitimacy. While some developed countries perceive the CERDS as a 'fundamental departure from the traditional rules of contemporary international law', developing countries do recognise the same Charter as 'a legally binding instrument imposing rights and obligations on states. ${ }^{25}$ Since it was supported primarily by all developing countries and secured little support from developed countries, ${ }^{26}$ the CERDS does not represent a consensual growth of the principle of PSNR. Though built on the same premise, the CERDS basically differs from the 1962 Resolution with regard to the applicability of international law, particularly in its emphasis on the domestic law of the host state for the settlement of disputes between the foreign investor and the host state. ${ }^{27}$ Thus, in comparison to the 1962 Resolution, the CERDS is a stronger statement of PSNR, with lesser global support.

The legal status of PSNR in international law can be assessed to some extent by evaluating the legal significance of resolutions of international organisations, in general, and the 1962 Resolution and the CERDS, in particular. Although resolutions of international organisations are not generally recognised as a formal source of international law under article 38 of the Statute of the International Court of Justice (ICJ), ${ }^{28}$ such resolutions indeed can 'contribute to the crystallisation or formation of new customary

21 See, eg, Franz Xaver Perrez, "The Relationship between "Permanent Sovereignty" and the Obligation not to Cause Transboundary Environmental Damage’ (1996) 26 Environmental L 1187.

22 Texaco Overseas Petroleum Company v California Asiatic Oil Company and the Government of Libyan Arab Republic (Compensation for Nationalised Property) (Award on the Merits) (1977) (1978) 17 ILM 1 (Texaco Arbitration) para 88.

23 See, eg, Legal Status of Eastern Greenland (Norway v Denmark) [1933] PCIJ Ser A/B, No 53, 71; Nuclear Tests (Australia v France) (Judgment) [1974] ICJ Rep 253, paras 43-45; Nuclear Tests (New Zealand $v$ France) (Judgment) [1974] ICJ Rep 457, paras 46-48; United States-Sections 301-10 of the Trade Act 1974 (European Union v United States)-Report of the Panel (22 December 1999) WT/DS152/R, paras 7.118, 7.121-7.123.

24 Perrez (n 21) 1197.

25 ibid.

26 ibid.

27 Jeswald W Salacuse, The Law of Investment Treaties (2nd edn, OUP 2015) 68-74.

28 Statute of the International Court of Justice (adopted 26 June 1945, entered into force 24 October 1945) 1 UNTS 16 . 
law. ${ }^{29}$ As for the 1962 Resolution, its acceptance came with a preponderant majority, including both developing and developed countries, and without the opposition of the leading capital-exporting countries. ${ }^{30}$ Further, the principle of PSNR was codified first in the common article 1(2) of the 1966 International Covenant on Civil and Political Rights (ICCPR $)^{31}$ and the 1966 International Covenant on Economic, Social and Cultural Rights (ICESCR), ${ }^{32}$ and subsequently in several other treaties. ${ }^{33}$ Moreover, the principle was applied in respect of the natural resources of Namibia even before its independence, ${ }^{34}$ thus demonstrating its applicability in both colonial and non-colonial situations.

The 1970 UN General Assembly Declaration on Principles of International Law concerning Friendly Relations and Cooperation among States in accordance with the Charter of the United Nations (Friendly Relations Declaration) recognises the right to self-determination as a principle of international law, ${ }^{35}$ but it does not incorporate the principle of PSNR. This means that the principle of PSNR does not always appear as an essential corollary of the principle of self-determination. If one reads the Friendly Relations Declaration along with the NIEO Declaration, PSNR emerges as a principle, not a general or fundamental principle, of international law. This draws attention to a rather flexible use of the term 'principle' in international law. It conveys that not all

29 International Law Association (ILA), Statement of Principles Applicable to the Formation of General Customary International Law (Final Report of the Committee, Committee on the Formation of Customary (General) International Law, Report of the 69th Conference, London 2000) 56.

30 It was adopted by a vote of 87 to 2 (France and South Africa) along with 12 abstentions (including the United Kingdom and the United States).

31 International Covenant on Civil and Political Rights (adopted 16 December 1966, entered into force 23 March 1976) 999 UNTS 171 (ICCPR).

32 International Covenant on Economic, Cultural and Social Rights (adopted 19 December 1966, entered into force 3 January 1976) 993 UNTS 3 (ICECSR).

33 See, eg, Vienna Convention on Succession of States in respect of Treaties (adopted 23 August 1978, entered into force 6 November 1996) 1946 UNTS 3, art 13; African Charter on Human and Peoples' Rights (adopted 27 June 1981, entered into force 21 October 1986) 1520 UNTS 217, art 21; United Nations Convention on the Law of the Sea (adopted 10 December 1982, entered into force 16 November 1994) 1833 UNTS 396, art 193; Vienna Convention on Succession of States in Respect of State Property, Archives and Debts (adopted 7 April 1983, opened for signature 8 April 1983) Official Records of the UN Conference on Succession of States in Respect of State Property, Archives and Debts, vol II (UN Publication 2005) arts 15(4), 38(2); United Nations Framework Convention on Climate Change (adopted 9 May 1992, entered into force 21 March 1994) 1771 UNTS 107, preamble; Convention on Biological Diversity (adopted 5 June 1992, entered into force 29 December 1993) 1760 UNTS 79, preamble, art 3; Energy Charter Treaty (adopted 17 December 1994, entered into force 16 April 1998) 2080 UNTS 95, art 18(1).

34 In the 1960s, intensive foreign mining operations carried out in Namibia forced the UN Council for Namibia to enact Decree No 1 for the Protection of the Natural Resources of Namibia. Pursuant to that Decree, 'no person or entity could search for, take or distribute any natural resources found in Namibia without the Council's permission'. It was made clear that '[a]ny person or entity contravening the Decree could be held liable for damages by the future government of an independent Namibia': see UN, 'Namibia-UNTAGBackground' <http://www.un.org/en/peacekeeping/missions/past/untagS.htm\#UNTAG> accessed 17 November 2015.

35 Declaration on Principles of International Law concerning Friendly Relations and Co-operation among States in accordance with the Charter of the United Nations, UNGA Res 2625 (XXV) (24 October 1970) UN Doc A/RES/25/2625, principle 5. 
principles of international law have equal legal status: some may reach the status of jus cogens, while others may remain as principles in common parlance. As for the principle of PSNR, it has been treated as a jus cogens by some, ${ }^{36}$ and merely as a principle by many others. ${ }^{37} \mathrm{~A}$ view has been expressed that the principle of PSNR is one of the elements of the principles of the sovereign equality of states and of non-intervention, ${ }^{38}$ both of which find expression in articles 2(1) and 2(4) of the UN Charter, respectively. The provisions of the UN Charter enjoy special status by virtue of its supremacy clause under article $103 .{ }^{39}$ Since the meaning and scope of article 103 of the UN Charter remain imprecise and inconclusive, ${ }^{40}$ it would be difficult to conclude that the principle of PSNR enjoys the benefit of the supremacy clause of the UN Charter by virtue of being an element of its articles 2(1) and 2(4). By the same logic, one cannot completely rule out the possibility of the entanglement of the principle of PSNR with those UN Charter obligations that are considered supreme beyond any doubt in some specific situations.

Unlike the CERDS, the NIEO Declaration was adopted without any opposing vote, implying that developed states had no objection to the characterisation of PSNR as a principle of international law, but they were reluctant to recognise the same principle as an inalienable right of states, peoples or individuals. Even the end of the Cold War has not constrained developed countries from maintaining their stand towards PSNR as a principle in international law. This is evident from the 2008 UN General Assembly Resolution titled 'Strengthening Transparency in Industries', which recalls the 1962 Resolution and reaffirms that 'every State has and shall freely exercise full permanent sovereignty over all its wealth, natural resources and economic activities. ${ }^{41}$ It is also noticeable from the 2008 UN General Assembly Resolution, as well as the 2013 General Assembly Resolution, ${ }^{42}$ titled 'The Law of Transboundary Aquifers', which recalls the 1962 Resolution and recognises each aquifer state's 'sovereignty over the portion of a transboundary aquifer or aquifer system located within its territory. ${ }^{43}$ Both the 2008 and

36 Eduardo Jiménez de Aréchaga, François Ernest Robert Rigaux and Subrata Roy Chowdhury are the prominent proponents of the thesis that the principle of PSNR is jus cogens: see Schrijver, Sovereignty over Natural Resources (n 4) 375. Also, among others, Ian Brownlie and Alexander Orakhelashvili consider that the principle is of a peremptory character. See, respectively, Ian Brownlie, 'Legal Status of Natural Resources in International Law' (1979) 162 Recueil des Cours 245, 255, and Alexander Orakhelashvili, Peremptory Norms in International Law (OUP 2008) 52-53.

37 See, eg, Schrijver, Sovereignty over Natural Resources (n 4) 377.

38 Margot E Salomon, 'From NIEO to Now and the Unfinishable Story of Economic Justice' (2013) 62 ICLQ $31,33$.

39 Among the 'Miscellaneous Provisions' of the UN Charter, art 103 enshrines the supremacy clause thus: 'In the event of a conflict between the obligations of the Members of the United Nations under the present Charter and their obligations under any other international agreement, their obligations under the present Charter shall prevail.'

40 See, among others, Rain Liivoja, 'The Scope of the Supremacy Clause of the United Nations Charter' (2008) 57 ICLQ 583.

41 UNGA Res 62/274 (11 September 2008) UN Doc A/RES/62/274, preamble.

42 UNGA Res 68/118 (16 December 2013) UN Doc A/RES/68/118.

43 ibid art 3. 
2013 UN resolutions on the law of transboundary aquifers require each aquifer state to exercise its sovereignty 'in accordance with international law and the present articles' of the respective Resolutions. ${ }^{44}$ These Resolutions seek to balance the rights of each aquifer state by imposing a duty to utilise transboundary aquifers or aquifer systems according to the principle of 'equitable and reasonable utilisation', ${ }^{45}$ which is reminiscent of the principle of sustainable development.

On a few occasions, the UN Security Council has taken serious note of the violations of the principle of PSNR in specific countries, although without mentioning the 1962 Resolution as such. For instance, the UN Security Council has adopted resolutions against the violations of the principle of PSNR in the Democratic Republic of the Congo (DRC) ${ }^{46}$ and Liberia. ${ }^{47}$ Keeping in view the findings and recommendations of the Panel of Experts on the Illegal Exploitation of Natural Resources and Other Forms of Wealth in the Democratic Republic of the Congo, ${ }^{48}$ the UN Security Council has taken a host of measures to re-establish the sovereignty of the DRC over its natural resources. ${ }^{49}$ In the process, an unprecedented international architecture has emerged to redress the serious violations of the principle of PSNR in the Great Lakes Region. Even the most ardent supporters of the 1962 Resolution perhaps did not imagine at the time of its adoption that the violations of the principle of PSNR would one day prompt the UN Security Council to take enforcement measures under chapter VII of the UN Charter.

Besides its expression in a number of resolutions of international organisations and texts of several multilateral treaties in the fields of the environment, human rights, state succession, law of the sea, international energy and investment law, PSNR has found its recognition in quite a few awards and decisions of international adjudicatory bodies. ${ }^{50}$ In the Texaco Arbitration, for instance, the legal significance of various resolutions on the NIEO Declaration, as well as the possible existence of a customary norm resulting from those resolutions, were considered by the arbitral tribunal. The Sole Arbitrator concluded that the 1962 Resolution reflected the state of existing customary international law, ${ }^{51}$ thus recognising the principle of PSNR outlined in the 1962 Resolution as a customary norm of international law. However, the Sole Arbitrator did not hold the same for the CERDS. Similarly, according to the three-member tribunal in the Aminoil Arbitration, the 1962 Resolution enshrines ' $\mathrm{t}$ ] he most general formulation of the rules applicable for

44 ibid.

45 ibid art 5.

46 UNSC Res 1457 (24 January 2003) UN Doc S/RES/1457.

47 UNSC Res 1521 (22 December 2003) UN Doc S/RES/1521.

48 Panel of Experts on the Illegal Exploitation of Natural Resources and Other Forms of Wealth of the Democratic Republic of the Congo, 'Final Report' (16 October 2002) UN Doc S/2002/1146.

49 UNSC Res 2198 (29 January 2015) UN Doc S/RES/2198, paras 20-26.

50 Nico Schrijver, 'Fifty Years Permanent Sovereignty over Natural Resources: The 1962 UN Declaration as the Opinio Iuris Communis' in Marc Bungenberg and Stephan Hobe (eds), Permanent Sovereignty over Natural Resources (Springer 2015) 15-28, 24-26.

51 Texaco Arbitration (n 22) para 87. 
a lawful nationalisation' whereas the CERDS contains the 'most disputed clause' on the same subject. $^{52}$

Unlike the international tribunals in the Aminoil Arbitration and the Texaco Arbitration, the ICJ in the case of Armed Activities on the Territory of the Congo (Democratic Republic of the Congo v Uganda) did not dissociate the 1962 Resolution from the CERDS. ${ }^{53}$ It recalled that the principle of PSNR is expressed in the 1962 Resolution and 'further elaborated' in the NIEO Declaration and the CERDS. ${ }^{54}$ Thus, without underlining the differences between the 1962 Resolution and the CERDS, the ICJ sought to settle the issue of legal significance of PSNR, '[w]hile recognising the importance of this principle, which is a principle of customary international law. ${ }^{55}$

The scope of the principle of PSNR was also at stake in the case of Armed Activities on the Territory of the Congo, where the core issue was whether 'illegal exploitation, plundering and looting of the DRC's natural resources' by the Ugandan military forces constituted violations by Uganda of 'the sovereignty and territorial integrity of the DRC, more specifically of the DRC's sovereignty over its natural resources' ${ }^{56}$ While recognising the importance of the principle of PSNR as part of customary international law, the ICJ held that said principle was 'not applicable to the specific situation of looting, pillage and exploitation of certain natural resources by members of the army of a State militarily intervening in another State. ${ }^{57}$ Accordingly, the principle of PSNR was not contemplated to serve as a guiding post in all kinds of situations, and its limitations become evident at the time of its application.

\section{PSNR in the context of international human rights law}

After the adoption of the Universal Declaration of Human Rights in $1948,{ }^{58}$ the UN Commission on Human Rights (the predecessor of the UN Human Rights Council) began drafting the ICCPR and the ICESCR (together, the International Covenants on Human Rights). During this process, the members of the Commission had discussions about the right to self-determination. In this regard, Chile proposed that the right of the peoples to self-determination should also include PSNR. ${ }^{59}$ Western countries opposed the Chilean proposal on the ground that the Commission on Human Rights was not

52 Award in the Matter of an Arbitration between Kuwait and the American Independent Oil Company (AMINOIL) (1982) 21 ILM 976 (Aminoil Arbitration) paras 143-44.

53 Armed Activities on the Territory of the Congo (Democratic Republic of the Congo v Uganda) (Judgment) [2005] ICJ Rep 168.

54 ibid para 244.

55 ibid.

56 ibid para 226.

57 ibid para 244.

58 Universal Declaration of Human Rights (adopted 10 December 1948) UNGA Res 217 A(III).

59 Schrijver, Sovereignty over Natural Resources (n 4) 49. 
competent to deal with the rights and duties of the state. ${ }^{60}$ But the former Soviet Union supported the Chilean proposal, claiming that those who were opposing the proposal were either under the fear of losing colonial domination or wanted to perpetuate the economic exploitation of the territories under their control. ${ }^{61}$

Even after the acceptance of the Chilean proposal, which found expression in the 1952 UN General Assembly Resolution on the 'Inclusion in the International Covenant or Covenants on Human Rights of an Article relating to the Right of Peoples to SelfDetermination, ${ }^{62}$ developed and developing countries continued to debate the subject of peoples' and states' right to PSNR. In 1954, the debate at the Commission on Human Rights culminated in the formulation of the common article 1 of the two Draft International Covenants on Human Rights. ${ }^{63}$ The common article 1 read as follows:

1. All peoples and all nations shall have the right of self-determination, namely, the right freely to determine their political, economic, social and cultural status.

2. All States, including those having responsibility for the administration of NonSelf-Governing and Trust Territories and those controlling in whatsoever manner the exercise of that right by another people, shall promote the realisation of that right in all their territories, and shall respect the maintenance of that right in other States, in conformity with the provisions of the United Nations Charter.

3. The right of peoples to self-determination shall also include permanent sovereignty over their natural wealth and resources. In no case may a people be deprived of its own means of subsistence on the grounds of any rights that may be claimed by other States.

The recognition of the right to PSNR as part of the right to self-determination was contested by Western countries because for them the principle of self-determination had nothing to do with control over natural resources, which was an attribute of sovereignty. According to the opponents, if the principle of PSNR were accepted as a right in a treaty, it would be 'a potential threat to foreign investment and international co-operation for the economic development of the under-developed areas. ${ }^{64}$ However, this opposition could not withstand the advocacy of the right to self-determination, including PSNR, by both developing countries and socialist countries. These countries emphasised that the proposal for the incorporation of the right to PSNR into the human rights Covenants 'was not intended to frighten off foreign investment by a threat of expropriation or

60 ibid 50 .

61 ibid.

62 UNGA Res 545 (VI) (5 February 1952) UN Doc A/C/3/SR.399.

63 Draft International Covenants on Human Rights: Report of the 3rd Committee (29 November 1954) UN Doc A/2808.

64 Schrijver, Sovereignty over Natural Resources (n 4) 58-59. 
confiscation; it was intended rather to warn against such foreign exploitation as might result in depriving the local population of its own means of subsistence. ${ }^{65}$

The incorporation of the principle of PSNR into the Draft International Covenants on Human Rights in 1954 was followed by the establishment of the Commission on Permanent Sovereignty over Natural Resources by the UN General Assembly in $1958 .{ }^{66}$ In May 1959, Chile advanced its view that '[f]reedom and independence counted for nothing if they had no economic basis. ${ }^{67}$ Chile and the former Soviet Union also submitted that the right of peoples and nations to PSNR 'must be exercised for the benefit of the people of the State concerned. ${ }^{68}$ On the other hand, the opponents maintained that 'self-determination was recognized as a "principle" and not as a "right" in the UN Charter and that it was doubtful whether the legal concept of "permanent sovereignty over natural wealth and resources" did in fact exist in international law. ${ }^{69}$ Obviously, the opponents were reluctant to accept any change in the old body of international law. Interestingly, the opponents found that 'the existing international law on foreign investment was for most investors incomplete, vague, contested and without an effective enforcement mechanism, ${ }^{70}$ but they saw no problem with the same law in respect of the host state.

The adoption of the 1960 Declaration on the Granting of Independence to Colonial Countries and Peoples without opposition came as a turning point in the history of the UN. ${ }^{71}$ It encouraged the adoption of the 1962 Resolution on PSNR without much opposition. Four years later, the UN General Assembly also adopted the International Covenants on Human Rights with the common article 1 on the right to self-determination, including PSNR. ${ }^{72}$ In the process, the UN General Assembly also embedded in the International Covenants on Human Rights a common provision that '[n] othing in the present Covenant shall be interpreted as impairing the inherent right of all peoples to enjoy and utilise fully and freely their natural wealth and resources. ${ }^{73}$ Common article 1(2) of the International Covenants qualifies the exercise of the right to PSNR 'without prejudice to any obligations arising out of international economic cooperation, based upon the principle of mutual benefit, and international law', whereas the common provision under article 25 of the ICESCR and article 47 of the ICCPR does not contain such a qualification. This may give rise to the impression that PSNR appears

65 Annotations on the text of the Draft International Covenants on Human Rights (1 July 1955) UN GAOR 10th Session, UN Doc A/2929, 15.

66 Recommendations concerning International Respect for the Right of Peoples and Nations to Selfdetermination, UNGA Res 1314 (XIII) (12 December 1958) UN Doc A/RES/1188, para 1.

67 Schrijver, Sovereignty over Natural Resources (n 4) 60.

68 ibid 65.

69 ibid 68.

70 Salacuse (n 27) 86.

71 Declaration on the Granting of Independence to Colonial Countries and Peoples (14 December 1960) UNGA Res 1514 (XV).

72 ICCPR, art 1; ICECSR, art 1.

73 ICECSR, art 25; ICCPR, art 47. 
at two places in the ICCPR, as well as in the ICESCR, ${ }^{74}$ without textual consistency. However, the drafting history of the International Covenants does not uphold the impression of inconsistency in their PSNR-related provisions. While the common article 1(2) was drafted in the language of rights, the common provision under article 25 of the ICESCR and article 47 of the ICCPR was incorporated to reiterate a principle of international law. There was no intention to codify PSNR inconsistently.

In this way, the recognition of the right of peoples exercising permanent sovereignty over their natural resources came first from the 1954 Draft International Covenants on Human Rights, and then from the 1962 Resolution on PSNR. The Commission on Human Rights made as much of a contribution to the recognition of PSNR as a right as the Commission on Permanent Sovereignty over Natural Resources did for presenting this right as a principle. Like the right to self-determination, the right to PSNR establishes a bridge between economic, social and cultural rights and civil and political rights. It provides a common ground for first- and second-generation human rights. Further, it illustrates that all human rights are interdependent and interrelated. Consequently, the denial of the principle/right of PSNR violates not only the economic right of the peoples and the nation but it is also contrary to human rights.

While the right to self-determination, including PSNR, is a stand-alone right in the common part I of the International Covenants on Human Rights, the right to PSNR is one of the mainstream human rights under article 21 of the 1981 African Charter on Human and Peoples' Rights (African Charter). In fact, without its merger with the right to self-determination, the right to PSNR as such appears under article 21 of the African Charter thus:

1. All peoples shall freely dispose of their wealth and natural resources. This right shall be exercised in the exclusive interest of the people. In no case shall a people be deprived of it.

2. In case of spoliation the dispossessed people shall have the right to the lawful recovery of its property as well as to an adequate compensation.

3. The free disposal of wealth and natural resources shall be exercised without prejudice to the obligation of promoting international economic cooperation based on mutual respect, equitable exchange and the principles of international law.

4. States parties to the present Charter shall individually and collectively exercise the right to free disposal of their wealth and natural resources with a view to strengthening African unity and solidarity.

5. States parties to the present Charter shall undertake to eliminate all forms of foreign exploitation particularly that practiced by international monopolies so as to enable their peoples to fully benefit from the advantages derived from their national resources. 
This goes well beyond the common article 1(2) of the International Covenants on Human Rights. It embodies one of the 'third-generation rights ${ }^{75}$ and its violations have been taken seriously by the monitoring bodies of the African Charter. ${ }^{76}$ As a result, the African Charter has not only helped establish the peoples-oriented right to PSNR as an integral part of international human rights law but it has also provided this right its own identity.

The adoption of the 2007 Declaration on the Rights of Indigenous Peoples (2007 Declaration) introduced a new thrust into the principle of PSNR. ${ }^{77}$ Like the CERDS, the 2007 Declaration did not get the support of some of the developed states at the time of its adoption by the UN General Assembly. ${ }^{78}$ However, the widespread support for the rights of indigenous peoples suggests that the opposition of a few states does not necessarily affect the legal significance of these rights. Without recalling the 1962 Resolution, the 2007 Declaration articulates the rights of indigenous peoples to their natural resources thus:

1. Indigenous peoples have the right to the lands, territories and resources which they have traditionally owned, occupied or otherwise used or acquired.

2. Indigenous peoples have the right to own, use, develop and control the lands, territories and resources that they possess by reason of traditional ownership or other traditional occupation or use, as well as those which they have otherwise acquired.

3. States shall give legal recognition and protection to these lands, territories and resources. Such recognition shall be conducted with due respect to the customs, traditions and land tenure systems of the indigenous peoples concerned. ${ }^{79}$

The 2007 Declaration further provides that '[i]ndigenous peoples shall not be forcibly removed from their lands or territories' and that ' $[\mathrm{n}] \mathrm{o}$ relocation shall take place without the free, prior and informed consent of the indigenous peoples concerned and

75 African Commission on Human and Peoples' Rights, Antonie Bissangou $v$ Republic of Congo, Communication No 253/02 (15-29 November 2006), Decision adopted at the 40th session (Merits) para 80 .

76 In the case of The Social and Economic Rights Action Centre and the Centre for Economic and Social Rights $v$ Nigeria, for instance, the African Commission on Human and Peoples' Rights found, inter alia, a violation of art 21 of the African Charter because the Nigerian government had 'facilitated the destruction of Ogoniland' and allowed 'private actors, and the oil companies in particular, to devastatingly affect the wellbeing of the Ogonis'. See African Commission on Human and Peoples' Rights, The Social and Economic Rights Action Centre and the Centre for Economic and Social Rights v Nigeria, Communication No 155/96 (13-27 October 2001), Decision adopted at the 30th ordinary session (Merits) para 58.

77 United Nations Declaration on the Rights of Indigenous People, UNGA Res 61/295 (13 September 2007) UN Doc A/RES/61/295 (2007 Declaration).

78 The 2007 Declaration was adopted by a majority of 144 states in favour, 4 votes against (Australia, Canada, New Zealand and the United States) and 11 abstentions. While the CERDS was opposed by the leading capital-exporting states on ideological grounds, the 2007 Declaration was opposed by those developed states that had a significant population of indigenous peoples.

792007 Declaration, art 26. 
after agreement on just and fair compensation and, where possible, with the option of return. ${ }^{80}$ In other words, the state has been subjected to certain unprecedented duties towards indigenous peoples. Contrary to the perceptions of the parochial state actors, this extraordinary regime strengthens the principle of PSNR by focusing on the well-being of the people. The principle necessarily includes the obligation to respect and protect the rights of peoples over their natural resources, and recognises that indigenous peoples deserve special consideration because of their vulnerability.

In addition to the rights of indigenous peoples in respect of their natural resources, the 2007 Declaration recognises their right to development in accordance with their own needs and interests. ${ }^{81}$ It further provides that '[i]ndigenous peoples deprived of their means of subsistence and development are entitled to just and fair redress. ${ }^{82}$ In the Case of the Mayagna (Sumo) Awas Tingni Community v Nicaragua, for instance, the Inter-American Court of Human Rights (IACtHR) asked the government of Nicaragua to 'invest, as reparation for immaterial damages (...) in works or services of collective interest for the benefit of the Mayagna (Sumo) Awas Tingni Community' and 'to create an effective mechanism' to protect 'the property of indigenous communities, in accordance with their customary law, values, customs and mores. ${ }^{83}$ While recognising the wide-ranging rights of indigenous peoples, the 2007 Declaration articulates the corresponding duties of states, thus adding a new category of jural correlatives that bring a new challenge to the balancing of the rights and duties of states, peoples, communities and individuals. Since some indigenous communities have a transnational presence in Africa, ${ }^{84}$ in particular, trans-border balancing of the rights and duties of these communities, the states concerned, and other stakeholders is a challenging task. In brief, the 2007 Declaration presents a special package of the rights to selfdetermination, development and PSNR; it highlights the peoples-oriented character of the principle of PSNR; and it successfully challenges international law orthodoxy.

Obviously, the human rights dimensions of the principle of PSNR are broader than those anticipated by the advocates of this principle in the 1960s and 1970s. Since the protection of the rights of foreign investors is part of the principle, the cases of violations of their rights may also attract the application of a human rights treaty if such violations affect the provisions of the treaty. In the case of OAO Neftyanaya Kompaniya Yukos $v$ Russia, ${ }^{85}$ for instance, the European Court of Human Rights held that the Russian

80 ibid art 10.

81 ibid preamble, para 6, art 23.

82 ibid art 20(2).

83 Case of the Mayagna (Sumo) Awas Tingni Community v Nicaragua (Merits, Reparations and Costs) InterAmerican Court of Human Rights Series C No 79 (31 August 2001) (Mayagna (Sumo) Awas Tingni Community) para 173.

84 African Commission on Human and Peoples' Rights, Advisory Opinion on the United Nations Declaration on the Rights of Indigenous Peoples, Opinion adopted at the 41st ordinary session (16-30 May 2007) para 30.

85 OAO Neftyanaya Kompaniya Yukos v Russia App no 14902/04 (European Court of Human Rights, 20 September 2011) (OAO Neftyanaya). 
Federation had violated, inter alia, the right to a fair hearing (under article 6(1) of the 1950 European Convention on Human Rights and Fundamental Freedoms) ${ }^{86}$ of the applicant company by resorting to unfair use of the legal and tax system of the state. ${ }^{87}$ Later, the European Court asked the Russian Federation to pay US\$2.51 billion in damages to the shareholders of OAO Neftyanaya Kompaniya Yukos, ${ }^{88}$ the company which had gone bankrupt.

While the Awas Tingni Community case ${ }^{89}$ applied the principle of PSNR as enshrined in the Draft Declaration on Discrimination against Indigenous Peoples ${ }^{90}$ to enhance the rights of individuals/communities against the state concerned, the Yukos case rendered the corresponding rights of the state concerned subservient to the human rights of the complaining individuals. If these cases are read together, one may observe that the principle of PSNR has contributed more to the development of the rights of individuals/ communities than those of states. Consequently, the principle has as much potential to protect the rights of individuals, communities and foreign investors, including both natural and juridical persons, as that of states. This indicates an increasing engagement between international human rights law and international investment law. Also, it signifies a change in the balance of rights and duties of states. Now, in the field of human rights, states are endowed with a larger number of duties and can no longer claim to be the chief beneficiaries of the right to PSNR.

\section{PSNR in the context of international investment law}

The movement for the development of the principle of PSNR during the 1950s-1970s was essentially a collective response to the experiences of developing countries in the field of international investment law. With its colonial legacy, the traditional international investment law contained some controversial features, especially concession agreements and the Hull formula, which proved to be detrimental to the interests of these countries. ${ }^{91}$ Also, despite the Calvo doctrine, developing countries remained exposed to traditional

86 European Convention for the Protection of Human Rights and Fundamental Freedoms (adopted 4 November 1950, entered into force 3 September 1953) ETS No 5.

87 OAO Neftyanaya (n 85).

88 ibid.

89 Mayagna (Sumo) Awas Tingni Community (n 83). In this case, the IACtHR found the government of Nicaragua in violation of arts 21 (the right to property) and 25 (the right to judicial protection) of the American Convention on Human Rights in respect of the Mayagna (Sumo) Awas Tingni Community (American Convention on Human Rights (adopted 22 November 1969, entered into force 18 July 1978) 1144 UNTS 123). It therefore asked the government 'to create an effective mechanism' to protect 'the property of indigenous communities, in accordance with their customary law, values, customs and mores' (Mayagna (Sumo) Awas Tingni Community (n 83) para 173).

90 Draft Declaration on the Rights of Indigenous Peoples, UN Res 1995/32 (3 March 1995) UN Doc E/CN.4/2006/79.

91 See, among others, Kate Miles, The Origins of International Investment Law: Empire, Environment and the Safeguarding of Capital (CUP 2013) 28. 
international law and procedure for the settlement of their disputes with foreign investors that were essentially a matter of domestic jurisdiction. ${ }^{92}$ Since developing countries wanted to assert their national sovereignty over the persons and their acts and assets within their jurisdiction, in 1961 the Asian-African Legal Consultative Committee emphasised the primacy of domestic law in the Principles Concerning Admission and Treatment of Aliens. ${ }^{93}$ Ramcharan, a distinguished international lawyer from the Caribbean, summarised the situation thus:

The approach of the Asian-African Legal Consultative Committee was similar to that of the Inter-American Juridical Committee inasmuch as it regarded the traditional laws on State responsibility as products of Western Europe, as being unfair, and as not being binding on the new States of Asia, Africa and Latin America. The Committees also shared a wish to re-write and reshape the traditional law. ${ }^{94}$

The 1962 Resolution came in the background of this cry for change. The principle of PSNR as found in the 1962 Resolution upholds the 'inalienable right of all States freely to dispose of their natural wealth and resources in accordance with their national interests. ${ }^{95}$ It recognises the right of a state to nationalise or expropriate the property of a foreign investor. At the same time, it provides that 'the owner shall be paid appropriate compensation, in accordance with the rules in force in the State taking such measures in the exercise of its sovereignty and in accordance with international law. ${ }^{96}$ In case of a dispute over the question of compensation, the 1962 Resolution stipulates the exhaustion of local remedies and contains the possibility of settlement of the dispute through arbitration or international adjudication if sovereign states and other parties concerned agree to invoke this mechanism. ${ }^{97}$

The 1962 Resolution contained a compromise 'between respect for national sovereignty and other rights and obligations under international law. ${ }^{98}$ It sought to satisfy developing countries by referring to domestic law on issues such as compensation to be paid for expropriation of foreign investment. Likewise, it attempted to assure developed countries by making reference to international law and to international adjudication to settle disputes pertaining to compensation for expropriation. It envisaged the standard

92 ibid.

93 According to the Asian-African Legal Consultative Organisation, Principles Concerning Admission and Treatment of Aliens (25 February 1961) <http://www.refworld.org/docid/44eae2224.html> accessed 17 November 2015, the right of an alien to acquire, hold and dispose of property is '[s]ubject to local laws, regulations, and orders and subject also to the condition, imposed for his admission into the State' (art 11). Also, the Principles envisaged thus: 'The State shall, however, have the right to acquire, expropriate or nationalise the property of an alien. Compensation shall be paid for such acquisition, expropriation or nationalisation in accordance with local laws, regulations and orders' (art 12).

94 Bertrand G Ramcharan, The International Law Commission: Its Approach to the Codification and Progressive Development of International Law (Martinus Nijhoff 1977) 184.

951962 Resolution, preamble.

96 ibid para 4 (emphasis added).

97 ibid.

98 Schrijver, Sovereignty over Natural Resources (n 4) 70. 
of 'appropriate' compensation, not 'prompt, adequate and effective' compensation. However, the 1962 Resolution left scope for a conflict of interpretation. For instance, in 1962 itself, the United States declared that in its view the word 'appropriate' was the equivalent of 'prompt, adequate and effective.9 99 That is why the 'appropriate' standard of treatment as well as the reference to international law was gradually diluted in two subsequent resolutions on the same topic. ${ }^{100}$ There was greater focus on domestic law to decide questions related to expropriation and compensation to be paid in case a foreign investment was expropriated. The NIEO movement sought to intensify efforts to give primacy to domestic law over international law in regulating and protecting foreign investment, and the CERDS came as a part of this process.

The CERDS seeks to address some of the inequities of traditional international investment law. In the spirit of the Calvo doctrine, article 2(2)(a) of the CERDS gives every state the right to regulate foreign investment in accordance with its domestic law and national priorities. Sensitive to the legitimate aspirations of developing countries, not all developed countries opposed the CERDS. For instance, in spite of voting against the 1962 Resolution, France voted in favour of the CERDS. However, other developed countries either abstained or voted against the CERDS. ${ }^{101}$ In particular, the leading capital-exporting countries opposed article 2(2)(a) of the CERDS because 'they wanted host countries to treat foreign investments as per what they thought to be their international obligations.' ${ }^{102}$ Similarly, the leading capital-exporting countries were unhappy with article 2(2)(b) of the CERDS, which gives every state the right to regulate and supervise the activities of transnational corporations (TNCs) within its domestic jurisdiction in accordance with its laws and national priorities. On the other hand, for developing countries, this provision was essential in the absence of any international code of conduct on TNCs.

Article 2(2)(c) of the CERDS recognises the right of every state to expropriate foreign investment and determine the amount of compensation according to its domestic law and national priorities. It further stipulates that any dispute over the question of compensation shall be decided by the national courts applying national law. Unlike the 1962 Resolution, the CERDS does not meet 'the demand of developed countries that the question of compensation should be decided according to the principles of international law, ${ }^{103}$ for 'developing countries denied the existence of any such principle.. ${ }^{104}$ In other

99 Frank G Dawson and Burns H Weston, "Prompt, Adequate and Effective": A Universal Standard of Compensation?' (1962) 30 Fordham L Rev 727; Restatement (Third) of the Foreign Relations Law of the United States (n 20) 206.

100 Permanent Sovereignty over Natural Resources (25 November 1966) UNGA Res 2158 (XXI); Permanent Sovereignty over Natural Resources (17 December 1973) UNGA Res 3171 (XXVIII).

101 The six opponents were: Belgium, Denmark, the Federal Republic of Germany, Luxembourg, the United Kingdom and the United States.

102 Prabhash Ranjan, 'India and Bilateral Investment Treaties-A Changing Landscape' (2014) 29 ICSID Rev 419, 424.

103 ibid 425 .

104 ibid. 
words, while developing countries deployed the principle of PSNR to strive towards their economic independence by challenging their subordination in the name of the established rules of international law, developed countries sensed dangers to their economic dominance by the primacy of domestic law. For these reasons, generally, developed countries attach no legal value to the CERDS. ${ }^{105}$ Indeed, the principle of PSNR was the bone of contention between developed and developing countries. The CERDS led to their showdown, and the North-South conflict pushed developing countries closer to socialist countries. This contestation prompted developed countries to promote a new architecture of international investment law by resorting to bilateral diplomacy with little risk of confronting the combined strength of developing countries and socialist countries.

4.1 Proliferation of bilateral investment treaties in the 1990s and departure from PSNR principles

While developing countries as a group were trying to get rid of the colonial yoke by invoking the principle of PSNR, most of them were also 'competing intensely with each other to attract foreign investment, ${ }^{106}$ and a few of them were entering bilateral agreements with developed countries not only to attract foreign investment but also to ensure protection of the investment. In other words, developed countries-West European countries to start with-designed the instrumentality of bilateral investment treaty (BIT) to bind developing countries in international treaty obligations to protect foreign investment because the traditional international protection, under existing international law, was under threat from the multilateral initiatives such as the CERDS and the NIEO. ${ }^{107}$ One can learn from the following comment of the reporters of the Restatement (Third) of the Foreign Relations Law of the United States that the capitalexporting countries have deployed BITs to make developing countries accept 'all or some of the terms' of the Hull formula:

The United States Government has consistently taken the position in diplomatic exchanges and in international fora that under international law compensation must be 'prompt, adequate and effective', and those terms have been included in United States legislation. (...) That formulation has met strong resistance from developing states and has not made its way into multilateral agreements or declarations or been universally utilised by international tribunals, but it has been incorporated into a substantial number of bilateral agreements negotiated by the United States as well as by other capital-exporting states both among themselves and with developing states. ${ }^{108}$

105 Salacuse (n 27) 84.

106 Antony Anghie, Imperialism, Sovereignty and the Making of International Law (CUP 2005) 236.

107 According to Salacuse (n 27) 84-85, the CERDS 'served to undermine the solidity of the traditional international legal framework for foreign investment and led both investors and their home countries to search for means to strengthen it in order to protect their economic interests in a new era'

108 Restatement (Third) of the Foreign Relations Law of the United States (n 20) 198. 
In this way, BITs became part of the strategy of developed countries to check multilateral economic diplomacy, where these countries had a comparative disadvantage. Although the first BIT came into existence in $1959,{ }^{109}$ when the principle of PSNR was struggling to get recognition in international law, such treaties did not become very popular until the mid-1990s. This is evident from the fact that only 200 BITs existed in 1980 and only 500 or so in 1990, whereas by the end of April 2015, this number reached more than $3200 .{ }^{110}$ The increasing number of BITs, which contained broad rules for protection of foreign investment, meant that developing countries were more and more willing to accept international law as the framework for regulation of foreign investment. This indicated a significant departure from the principle of PSNR in two ways. First, developing countries, by and large, accepted that the principle of paying compensation for expropriation of foreign investment should be guided by the principles laid down in the BIT, not domestic laws. Second, developing countries accepted that foreign investors could initiate international arbitral proceedings against their sovereign action under the BIT without necessarily exhausting local remedies. Since BITs sought to prune PSNR and subvert CERDS, these treaties represent the rise of the rights of foreign investors against sovereign rights in the name of widespread international investment law. It is an open secret that 'BITs give guarantees to investors but do not normally address obligations of investors. ${ }^{111}$ The unequal nature of BITs is reminiscent of unequal treaties, ${ }^{112}$ although a few commentators observe that 'the reality is little more nuanced than this. ${ }^{113}$ Since BITs are the mainstay of modern international investment law, there is a crisis of confidence.

\subsection{Are PSNR principles re-surfacing in international investment law?}

Treaties bring their signatories together with the prospects of international cooperation in the given fields, but their potential to create conflicts cannot be ruled out. BITs are no exception. The increase in the number of BITs in the last two decades or so (essentially,

109 See Treaty for the Promotion and Protection of Investments (with Protocol and exchange of notes) (Federal Republic of Germany-Pakistan) (adopted 25 November 1959, entered into force 28 April 1962) 457 UNTS 23.

110 This includes 2926 stand-alone investment treaties or BITs and 347 investment chapters in free trade agreements or international investment agreements. See UNCTAD, World Investment Report 2015: Reforming International Investment Governance (UN Publications 2015) 106.

111 Rudolf Dolzer and Christoph Schreuer, Principles of International Investment Law (2nd edn, OUP 2012) 25.

112 See, among others, Muthucumaraswamy Sornarajah, The International Law on Foreign Investment (3rd edn, CUP 2010) 39, 178-79, 188, 430.

113 For example, Ranjan draws attention to the fact that today there are a number of BITs signed between developing countries (eg, the 2011 Agreement between the Government of India and the Government of Nepal for the Promotion and Protection of Investments), where both countries seek to protect foreign investment. Ranjan also points out that, in several instances, BITs are being used by developing countries to protect their investment in developed countries. For example, in 2014, 40 per cent of BIT cases were brought against developed countries (see UNCTAD, World Investment Report 2015 (n 110) 112). Ranjan's comments are available on file with the author. 
1995-2015) has been followed by a corresponding increase in the number of disputes between foreign investors and host states. The number of known investment treaty disputes under arbitration has increased from little more than 50 in 1996 to 608 by the end of 2014. ${ }^{114}$ These disputes have meant that foreign investors, using BITs, have been able to challenge a wide array of sovereign regulatory measures. In other words, investment treaty arbitration (ITA) tribunals have decided whether these sovereign regulatory measures breach host countries' BIT obligations. This could have an adverse impact on a large part of the population of a host state and may involve the award of substantive damages to foreign investors, resulting in diversion of taxpayer's money to foreign investors. This has generated a backlash or contestation against international investment law $^{115}$ to the extent that Sornarajah, a leading expert on international investment law, calls the present system 'a fraudulent system.' ${ }^{116}$

The argument is that a small number of arbitrators from developed countries dominate the ITA world, and determine the public interests of the countries (which some say are mostly developing) involved in international investment disputes, and often apply controversial principles such as 'the fair and equitable treatment standard' as established jurisprudence. ${ }^{117}$ The democratic deficit of international investment law has become a matter of concern. ${ }^{118}$ Considering that international investment arbitration is an expensive procedure ${ }^{119}$ that may indeed produce awards of damages as high as US $\$ 1.061$ billion ( $a$ la the Oxy case) ${ }^{120}$ or even US\$50.2 billion (à la the Yukos case), ${ }^{121}$ the price of justice through the ITA route is too heavy. One may wonder whether developing countries can afford it.

114 UNCTAD, 'Recent Trends in IIAs and ISDS' (2015) 1 UNCTAD IIA Issues Note 1 <http://unctad.org/en/ PublicationsLibrary/webdiaepcb2015d1_en.pdf> accessed 5 July 2015.

115 See, among others, Asha Kaushal, 'Revisiting History: How the Past Matters for the Present Backlash against the Foreign Investment Regime' (2009) 50 Harvard Intl LJ 491; Louis T Wells, 'Backlash to Investment Arbitration: Three Causes' in Michael Waibel and others (eds), The Backlash Against Investment Arbitration: Perceptions and Reality (Kluwer Law International 2010).

116 Muthucumaraswamy Sornarajah, 'International Investment Law as Development Law: The Obsolescence of a Fraudulent System' (2015) (forthcoming; on file with author).

117 In this regard, Sornarajah has observed: 'It is, as if once gunboat diplomacy had failed, investment arbitrators are the insidious troops that are the hidden guardians of foreign investment dressed up in expensive civilian suits instead of military uniform' (ibid).

118 See, among others, Barnali Choudhury, 'Recapturing Public Power: Is Investment Arbitration's Engagement of the Public Interest Contributing to the Democratic Deficit?' (2008) 41 Vanderbilt J Transnatl L 775; Susan D Franck, 'The Legitimacy Crisis in Investment Treaty Arbitration: Privatising Public International Law through Inconsistent Decisions' (2004-05) 73 Fordham L Rev 1521.

119 Sornarajah, The International Law on Foreign Investment (n 112) draws attention to the fact that over 55 million dollars were spent on the arbitration of Fraport AG Frankfurt Airport Services Worldwide $v$ Republic of the Philippines (Award) ICSID Case No ARB/03/25 (16 August 2007).

120 Occidental Petroleum Corporation and Occidental Exploration and Production Company $v$ The Republic of Ecuador (Decision on Annulment of the Award) ICSID Case No ARB/06/11 (2 November 2015).

121 Hulley Enterprises Limited (Cyprus) v Russian Federation (Final Award) PCA Case No AA 226 (18 July 2014); Yukos Universal Limited (Isle of Man) v Russian Federation PCA Case No AA 227 (18 July 2014); Veteran Petroleum Limited (Cyprus) v Russian Federation (Final Award) PCA Case No AA 228 (18 July 2014). 
Reacting against international investment arbitration and reasserting their national sovereignty, some states have terminated their BITs and also withdrawn from those multilateral treaties that were used for instituting arbitration proceedings against them. Like the initiative for the recognition of the principle of PSNR, the revolt against BITs and international investment arbitration began in Latin America. In March 2008, Ecuador renounced nine of its BITs ${ }^{122}$ and, in July 2009, it served notice to withdraw from the 1965 Convention on the Settlement of Investment Disputes between States and Nationals of Other States (the ICSID Convention). ${ }^{123}$ Likewise, in May 2008, Venezuela terminated its BIT with the Netherlands because it felt that the treaty in question obstructed policy changes in its energy sector; ${ }^{124}$ in January 2012, it withdrew from the ICSID Convention. ${ }^{125}$ In July 2009, the Russian Federation terminated the provisional application of the 1994 Energy Charter Treaty. ${ }^{126}$ After reviewing its entire BIT programme, in September 2012, South Africa terminated its BIT with Belgium and Luxembourg and then renounced the BITs with Spain and Germany in 2013. ${ }^{127}$ Having encountered the arbitration challenge to its Black Economic Empowerment (BEE) programme, ${ }^{128}$ South Africa decided to construct domestic legislation for

122 UNCTAD, World Investment Report 2013: Global Value Chains: Investment and Trade for Development (UN Publication 2013) 108.

123 Convention on the Settlement of Investment Disputes between States and Nationals of Other States (adopted 18 March 1965, entered into force 14 October 1966) 575 UNTS 159. For preliminary information on Ecuador's withdrawal from the ICSID Convention, see Joshua M Robbins, 'Ecuador withdraws from ICSID Convention' (Practical Law, 12 August 2009) <http://uk.practicallaw.com/2-422-1266? service=arbitration> accessed 17 November 2015.

124 Luke E Peterson, 'Venezuela Surprises the Netherlands with Termination Notice of BIT; Treaty has been Used by Many Investors to "Route" Investments into Venezuela' (Investment Arbitration Reporter, 16 May 2008) <https://www.iareporter.com/articles/venezuela-surprises-the-netherlands-with-terminationnotice-for-bit-treaty-has-been-used-by-many-investors-to-route-investments-into-venezuela/> accessed 17 November 2015.

125 Elisabeth Eljuri and Ramón J Alvins, 'Venezuela Denounces the ICSID Convention' (Norton Rose Fulbright, 24 January 2012) <http://www.nortonrosefulbright.com/knowledge/publications/62427/venezueladenounces-the-icsid-convention $>$ accessed 17 November 2015.

126 For comments on the Russian termination, see, among others, Amelia Hadfield and Adnan AmkhanBanyo, 'From Russia with Cold Feet: EU-Russia Energy Relations, and the Energy Charter Treaty' (2013) 1 Intl J Energy Security \& Environmental Research 1.

127 Sean Woolfrey, 'Another BIT Bites the Dust' (Tralac, 30 October 2013) <http://www.tralac.org/discussions/ article/5342-another-bit-bites-the-dust.html> accessed 17 November 2015.

128 In Piero Foresti, Laura de Carli \& Others $v$ Republic of South Africa (Award) ICSID Case No ARB(AF)/07/01 (4 August 2010) the claimants (seven Italian nationals and one Luxembourg-incorporated company) argued, inter alia: that South Africa's Mining Charter 2004 and the Mineral and Petroleum Resources Development Act 2002 had introduced 'the notion of state custodianship of mineral rights' (para 55); that new public law powers of control by the state were 'incompatible with the common law notion of rights to minerals' (para 55); and that the BEE 'equity divestiture requirements established by the twin operation' of the legislation in question expropriated the minerals and mining rights of the companies in which the claimants had their shares (para 64). Pending the arbitration, South Africa granted new mineral rights in lieu of the old ones to the operating companies and, therefore, the claimants requested the arbitration tribunal to discontinue the arbitration. The tribunal discontinued the case and awarded costs to the respondent. 
regulating and protecting foreign investment instead of BITs. ${ }^{129}$ Outraged by the ICSID Tribunal's decision in its mining dispute with a British company, ${ }^{130}$ in March 2014, Indonesia expressed the intention to terminate all of its $67 \mathrm{BITs},{ }^{131}$ including one with the Netherlands that came to an end on 1 July 2015 . $^{132}$

Because of 'a steady increase in foreign investors challenging' national regulatory measures under BITs at international arbitration tribunals, several countries have considered terminating their BITs in the hope that their exit from these treaties will provide 'a high degree of immunity' to national 'regulatory measures impacting foreign investment from being challenged under international law. ${ }^{133}$ Although a number of states have not yet decided to terminate their BITs because of various constraints, the overall support for these treaties has been diluted in those countries. In India, for example, the Ministry of Commerce favoured termination of BITs, but the Ministry of Finance disagreed. The dissatisfaction with BITs is reflected in the 2015 Model Text for the Indian Bilateral Investment Treaty (2015 Model BIT) ${ }^{134}$ Like a host of other countries, ${ }^{135}$ India wants to revise its BITs primarily due to a number of BIT claims brought by foreign investors. ${ }^{136}$ It wishes to retain treaty protection to foreign investment, though in a diluted form in comparison to its existing BITs and rely more on domestic law. Although the 2015 Model BIT contains an investor-state dispute settlement provision, India has its own internal differences on this aspect and prefers to settle its disputes with foreign investors within its own jurisdiction.

129 Chantall Presence, 'MPs Pass Controversial Investment Bill' (IOL, 17 November 2015) <http://beta.iol. co.za/news/politics/mps-pass-controversial-investment-bill-1946816> accessed 24 November 2015.

130 Churchill Mining Plc v Indonesia (Decision on Jurisdiction) ICSID Case No ARB/12/14 and 12/40 (24 February 2014).

131 Herbert Smith Freehills LLP, 'Indonesia Indicates Intention to Terminate All of its Bilateral Investment Treaties?' (Herbert Smith Freeholds Dispute Resolution-Arbitration Notes, 20 March 2014) <http://hsfnotes. com/arbitration/2014/03/20/indonesia-indicates-intention-to-terminate-all-of-its-bilateral-investmenttreaties/> accessed 17 November 2015.

132 Netherlands Embassy in Jakarta, Indonesia, 'Termination Bilateral Investment Treaty' <http://indonesia. nlembassy.org/organization/departments/economic-affairs/termination-bilateral-investment-treaty.html> accessed 25 November 2015.

133 Prabhash Ranjan, 'Column: Get a BIT Pragmatic' (The Financial Express, 17 July 2014) <http://archive. financialexpress.com/news/column-get-a-bit-pragmatic/1270640> accessed 17 November 2015.

134 Model Text for the Indian Bilateral Investment Treaty (2015)<https://www.mygov.in/sites/default/files/ master_image/Model\%20Text\%20for\%20the\%20Indian\%20Bilateral\%20Investment\%20Treaty.pdf> accessed 17 May 2016. For a critique of the 2015 Model BIT, see Prabhash Ranjan, 'Comparing Investment Provisions in India's FTAs with India's Stand Alone BITs: Contributing to the Evolution of New Indian BIT Practice' (2015) 16 J World Investment \& Trade 899.

135 According to UNCTAD, at least 45 countries and four regional integration organisations are currently revising or have recently revised their model agreement. See UNCTAD, World Investment Report 2015 (n 110).

136 For reasons behind India's decision to review its BITs, see Ranjan, 'India and Bilateral Investment Treaties' (n 102). As of 22 November 2015, nine foreign investors have issued investment treaty arbitration notices to India and in some of these cases an arbitration tribunal has been constituted: see the search results generated at <http://www.italaw.com/search/site/India?f[0]=im_field_case_type\%3A1090> accessed 23 November 2015. 
The termination of a BIT implies that the parties to the treaty are no longer bound by its provisions governing regulation of foreign investment, although they will still be bound by the applicable customary rules of international law, general principles of law recognised by civilised nations and peremptory norms of international law. This gives them the right to treat foreign investment essentially according to their domestic laws, and thus go back to the era of the 1960s and 1970s, when developing countries invoked the principle of PSNR and argued for domestic laws as the framework to regulate foreign investment including issues such as compensation for expropriation and challenging the host country's regulatory power before the state's local courts. Since not many developing countries have terminated their BITs and some of them are still keen to enter into new BITs, ${ }^{137}$ the argument of PSNR principles re-surfacing through termination of BITs cannot be made for many developing countries. Further, grandfathering provisions or survival clauses in BITs do not allow the terminating/withdrawing state to enjoy freedom from its treaty obligations for quite some time. ${ }^{138}$ Thus, the battle of BITs does not reflect the traditional divide between developed and developing countries in the field of international investment law, in general, and the principle of PSNR, in particular.

\section{Can PSNR be accurately characterised as a fundamental right of states?}

The concept of sovereignty is the basic premise of the concept of PSNR. Unlike the former, however, the latter has struggled to achieve recognition in international law. The traditional international law with its Eurocentric nature had no place for the principle of PSNR, thus allowing the growth of colonialism, concession agreements, diplomatic protection, and intervention to protect nationals and their properties abroad. Even if one could trace some elements of PSNR in the traditional international law, only the powerful states had capacity to make use of them. Although the UN Charter introduced a new era, it required a considerable amount of time to find a place for the principle of PSNR in the body of international law. The demand for the recognition of the principle of PSNR came from developing countries after their long exploitation; socialist countries supported it, whereas developed countries either opposed it or gave a lukewarm response. The principle became acceptable to its opponents largely because of its generalities and political legitimacy. A radical change in the balance of voting power at the UN General Assembly catalysed the recognition of the principle. As soon as it started acquiring the status of a legal right, however, the principle encountered a host of challenges. The principle still faces challenges during the course of its application in different fields.

137 For example, China is keen to conclude BITs with the European Union and the United States.

138 Under the 1994 Energy Charter Treaty, art 47(3), eg, the withdrawing state remains bound to apply its provisions for as long as 20 years in respect of the investments made prior to the withdrawal came into effect. 
A categorical answer to the question whether PSNR can be accurately characterised as a fundamental right of states would amount to an oversimplification of the complex webs of norms that manifest PSNR in different fields. The international debate on PSNR began in the context of the right to self-determination of nations. Later, it moved on to the direction of international economic law. Subsequently, it entered the mainstream of international human rights law. Eventually, it expanded into the fields of international environmental law and international trade law. Since PSNR as a fundamental right of states has not been equally and uniformly developed in all these fields, any generalisation of the status of the said right is bound to conceal more than what it would reveal.

At least five factors appear to be responsible for the underdevelopment of PSNR as a fundamental right of states. First, the focus of the international debate has been on PSNR as a principle, rather than as a fundamental right of states. Secondly, PSNR has not been a beneficiary of enrichment through the well-established mechanisms of progressive development and codification of international law. Thirdly, PSNR has not been a priority of those states that generally shape the international law-making agenda. Fourthly, the PSNR debate has encountered ideological divisions since its inception, which constrained consensual growth of norms relating to PSNR. Finally, after its provocative appearance in the 1960s and 1970s, PSNR was almost forgotten until its revival in the new millennium. In relative terms, PSNR is most accurately characterised as a fundamental right of states in the field of international investment law. It was barely dealt with in the state practice of international trade law until the beginning of the new millennium, and international human rights law has ushered in the transformation of the state-centric nature of the right to PSNR into its peoplesoriented character.

In international investment law, PSNR signifies the fundamental right of the host state to regulate investment and to nationalise or expropriate investment. Although most BITs aim at 'promotion and protection' of investment, the sovereign right to regulate and expropriate investment is reaffirmed by most of these treaties themselves. At the same time, the rights to regulate and expropriate have corresponding obligations towards foreign investors in particular. While these rights are almost frozen, their corresponding obligations have grown by virtue of thousands of BITs and their proinvestor interpretations by a number of commentators and arbitration tribunals. There are quite a few controversial elements of even well-characterised obligations of states. Consequently, the impact of the large quantity and/or controversial elements of obligations of states on their fundamental rights are a matter of debate.

In the field of international human rights law, the initial version of the right to PSNR was designed to uphold the fundamental right of nations over their natural resources, and its subsequent versions underlined the basic rights of peoples in respect of the lands and natural resources traditionally owned/possessed/used by these peoples. By virtue of the 'P' in PSNR, a nation under colonial rule or a non-self-governing territory could not be deprived of its right over its natural resources or wealth by a 
colonial ruler or administering authority even if the resources or wealth remained under the ownership and control of the latter for a long time. Later, the ' $S$ ' in PSNR was transformed from its traditional tag of 'sovereign authority' to its modern meaning of 'sovereign responsibility'. As a result, the fundamental right to PSNR needs to be exercised in the public interest. In the event of exercising its right to PSNR at the cost of the interests of its people, the state concerned stands in breach of the public trust doctrine (PTD) and remains accountable. ${ }^{139}$ The density of the PTD is fairly high in respect of the rights of indigenous peoples, in particular, so much so that these peoples can invoke the right to PSNR against their own state. Consequently, the statecentric right to PSNR coexists with the peoples-oriented right to PSNR; the latter is considerably developed through certain declarations/resolutions of international organisations and the jurisprudence of the African and American human rights bodies in particular; and states feel obligated to modify even their international contractual commitments to meet their human rights obligations.

Since the right to development has matured into the right to sustainable development, international human rights law has come closer to international environmental law. Accordingly, states have 'the sovereign right to exploit their own resources pursuant to their own environmental and developmental policies.' ${ }^{140}$ The environment-trade link has enabled states to apply environmental protection standards and exercise their PSNR rights in international trade. It follows that states have a right to use and manage their natural resources for their economic development and to adopt conservation measures, encompassing measures 'to regulate and control' exploitation of those resources 'in the light of their own objectives and policy goals, including economic and sustainable development. ${ }^{141}$ In the China Rare Earths case, the use of expressions such as 'the general principle' of PSNR as 'a relevant rule of international law' indicates the constraints in characterising PSNR as a fundamental right of states owing to the weighty obligations of states under the law of the World Trade Organisation (WTO). ${ }^{142}$

Theoretically, rights and obligations as jural correlatives help shape each other. By this logic, since the fundamental rights of states are subject to an increasing number of obligations, the scope of those rights must have been decreased and consequently the accuracy of those rights must have become unsustainable. However, this may not be true in state practice. Moreover, the accuracy of a fundamental right of states does not necessarily determine its legal status. For example, whatever the limitations of the principle of and right to sovereign equality of states in both normative and functional terms, there is no doubt about the status of this fundamental right of states. The same

139 See, eg, Joseph Sax, 'The Public Trust Doctrine in Natural Resource Law: Effective Judicial Intervention' (1970) 68 Michigan L Rev 471.

140 UNGA, 'Report of the United Nations Conference on Environment and Development: Annex I-Rio Declaration on Environment and Development' (12 August 1992) UN Doc A/CONF.151/26.

141 China-Measures Related to the Exportation of Rare Earths, Tungsten and Molybdenum-Reports of the Panel (26 March 2014) WT/DS431/R, WT/DS432/R and WT/DS433/R (China Rare Earths) para 7.267. 142 ibid paras 7.262-7.263. 
logic applies to the principle of and right to PSNR, although this logic does not find its codified expression as much as the advocates of the said principle/right wish to have in place.

As a whole, there is consensus on the generalities of the principle of, and the right to, PSNR and the specifics of the principle/right have been left to be developed in light of the considerations that are relevant in a specific field. Consequently, the scope and limitations of PSNR as a fundamental right of states are a matter of occasional discussion, which takes a different course in a different context. Like other rights, the right to PSNR is not an absolute right of states and its limitations considerably depend on its context.

The exercise of the right to PSNR occasionally comes into conflict with the rights of other states and entities. For example, most international investment disputes are the result of this kind of conflict. Any normative conflict may be resolved either through an understanding between the parties concerned or an authoritative assessment of the hierarchy of norms applicable in the given case. The China Rare Earths case illustrates the implications of the characterisation of PSNR as a right of states and the effects of its application in conflict with the obligations of the right-exercising state and the rights of other states. The WTO Panel in this case sought to determine, inter alia, the extent to which China could exercise its right to PSNR in international trade. ${ }^{143}$ The Panel believed that China was not entitled to exercise its PSNR rights in breach of its WTO obligations, especially when the rationale of the trade restrictions in question was not justifiable. ${ }^{144}$ In the process, the Panel attempted to strike a balance between (a) the PSNR rights and WTO obligations of states; (b) the WTO rights and obligations of states; and (c) trade and non-trade-related concerns. ${ }^{145}$ This was essentially an exercise in assessing normative relativity in the context of international trade, where the authority of WTO law is well established by virtue of its codified expression in the form of covered agreements; the right to PSNR does not have the comparable advantage. Although the trade liberalisation objective prevailed over other non-trade related objectives in this case, the former does not prevent sovereign states from pursuing the latter as a matter of policy. In brief, the right to PSNR remains relevant in any normative balancing.

\section{Conclusion}

The concept of PSNR has a dual legal identity: it is a principle of international law and also a right of states. The journey of the concept of PSNR to its recognition as a principle, and then as a right, is a significant achievement of the dynamic process of progressive development of international law in the post-war period. While the principle is widely accepted, the right is frequently contested. The 1962 Resolution gives expression to the

143 ibid para 7.462 .

144 ibid.

145 ibid paras 5.19-5.57. 
principle, and the CERDS to the right in its plural form. However, the 1962 Resolution is not the complete expression of the principle, nor is the CERDS the comprehensive statement of the right. While the principle is expanded through a series of developments such as the NIEO Declaration, the right is elaborated with the help of a number of instruments, such as the 2007 Declaration on the Rights of Indigenous Peoples.

A principle of law assumes the form of a legal right when the former is developed in operational terms in specific contexts, including the identifications of the rightholder, the duty-bearer, and their relations inter se. The basic difference between a legal principle and a legal right relates to their forms of expression: the former is articulated in an open language to provide a general guidance, and the latter is formulated in relatively more precise language to govern legal relationships in specific contexts. Since the rights emanating from PSNR are not the exclusive advantages of one state, but available to all states and peoples, they represent a general principle of international law. At the same time, the principle of PSNR does not appear in the category of the fundamental principles of international law that find expression, for instance, in article 2 of the UN Charter and the Friendly Relations Declaration. However, one can read this principle within the terms of certain fundamental principles, such as sovereign equality and selfdetermination.

The adjective 'permanent', attached to the expression 'sovereignty over natural resources', may appear to be a misfit in this ever-changing world, especially when a sovereign state has a right even to cede its territory or part thereof. However, it has a historical significance in the sense that sovereignty over natural resources of nations under the colonial rule was presumed to be permanently vested in those nations, and that their colonial masters were considered to be ineligible to acquire it or alienate it. In the contemporary world, the adjective signifies that the ultimate control over natural resources of a state remains with the state; that national laws remain applicable to those resources even if those resources are subjected to international contracts and owned/ possessed by foreign investors; that the state can exercise its sovereign rights over its natural resources any time; and that the state remains entitled to expropriate the assets of foreign investors and regain its control over those resources in accordance with the procedure established by law. While the adjective in the initial version of PSNR was primarily meant to underline the inalienability of sovereignty over natural resources, it serves the purpose of maintaining regulatory control over those resources in the contemporary world.

The recognition of the principle of PSNR in various fields, ranging from human rights to the environment, proves its wider acceptance and general application. The reliance of the 2008 and 2013 UN General Assembly resolutions on trans-boundary aquifers on the 1962 Resolution shows the acceptance of its provisions even in the current context. The human rights dimensions of the principle of PSNR became broader than those anticipated by the advocates of this principle in its initial stage. The growth of the right to PSNR has transformed its character. The peoples-oriented character of the right underlines the responsibility of states towards their peoples in respect of the use 
of natural resources. It indicates that in case of a conflict between the sovereign rights of states and the fundamental rights of peoples, generally, the latter deserve protection.

The wider acceptance of PSNR does not mean that it has become an overriding principle in international law. The limitations of the principle of and the right to PSNR come into light at the time of its application in specific contexts, especially in the fields of international trade and investment. Neither the principle of nor the right to PSNR has overriding effects to negate the obligations of states that they have freely assumed under international agreements, although the principle/right remains an important consideration in balancing competing legal interests of the parties involved in a given case. Since the nation-state system remains the bedrock of international law, states continue to enjoy their primordial position and exercise their regulatory powers over their natural resources by virtue of the concept/principle/right of PSNR. Following the emergence of new economies and the decline of some older ones, the revival of the concept of PSNR both as a principle and as a right seems to be a logical phenomenon. 